\title{
CIC-DUX sarcomas demonstrate frequent MYC amplification and ETS-family transcription factor expression
}

Steven Christopher Smith 1,2,6,7 , Darya Buehler ${ }^{3,6}$, Eun-Young Karen Choi ${ }^{1}$, Jonathan B McHugh ${ }^{1}$, Brian P Rubin ${ }^{4}$, Steven D Billings ${ }^{4}$, Bonnie Balzer ${ }^{2}$, Dafydd G Thomas ${ }^{1}$, David R Lucas ${ }^{1}$, John R Goldblum ${ }^{4}$ and Rajiv M Patel ${ }^{1,5}$

${ }^{1}$ Department of Pathology, University of Michigan Health System, Ann Arbor, MI, USA; ${ }^{2}$ Department of Pathology and Laboratory Medicine, Cedars-Sinai Medical Center, Los Angeles, CA, USA; ${ }^{3}$ Department of Pathology and Laboratory Medicine, University of Wisconsin Hospital, Madison, WI, USA; ${ }^{4}$ Department of Anatomic Pathology, Cleveland Clinic, Cleveland, OH, USA and ${ }^{5}$ Department of Dermatology, University of Michigan Health System, Ann Arbor, MI, USA

\begin{abstract}
Recent molecular advances have identified a novel, clinically aggressive subgroup of undifferentiated round cell sarcomas defined molecularly by oncogenic fusion of the gene, CIC, and either DUX4 or its paralog, DUX4L, herein termed CIC-DUX sarcomas. Morphologically, CIC-DUX sarcomas are round cell sarcomas with high-grade nuclear features, including vesicular chromatin and nucleoli, patchy clear cell foci, myxoid change, and necrosis. Here, we studied a cohort of 10 cases, including 6 newly identified cases, 2 with paired metastases. Given our prior observation of trisomy 8 in these tumors, we assayed for amplification and expression of $M Y C$ (cMyc) and representative downstream targets. Trisomy 8 was detected in 5/7 testable cases, with further amplification of MYC locus in 6/7 testable cases and immunohistochemical expression of MYC in 10/10. The canonical MYC transcriptional target, p21, but not MTDH, was differentially expressed compared with Ewing sarcomas. Given prior observation of induction of ETS-family transcription factors by the fusion oncoprotein, we assayed and identified highly prevalent positivity for ERG (9/10) and FLI1 (8/8). These findings are cautionary regarding use of these immunostains in prospective case workup, whereas the prevalent $M Y C$ amplification may represent a therapeutically targetable oncogenic pathway in CIC-DUX sarcomas.

Modern Pathology (2015) 28, 57-68; doi:10.1038/modpathol.2014.83; published online 20 June 2014
\end{abstract}

Recent molecular efforts have identified that a significant subset ${ }^{1}$ of undifferentiated small round cell sarcomas harbor a recurrent translocation, involving the gene, CIC (capicua transcriptional suppressor), on chromosome 19, fused with one of two poorly understood genes, either DUX4 (double homeobox 4), on chromosome 4 or its paralog, DUX4L (double homeobox 4-like), on chromosome 10, resulting in either $C I C-D U X 4, \mathrm{t}(4 ; 19)(\mathrm{q} 35 ; \mathrm{q} 13)$ or CIC-DUX4L, t(10;19)(q26;q13) fusions. These

Correspondence: Dr RM Patel, MD, Pathology, University of Michigan, 3261 Medical Science I, 1301 Catherine St, Ann Arbor, Michigan 48109-5602, USA

E-mail: rajivpat@med.umich.edu

${ }^{6}$ These are co-first authors.

${ }^{7}$ Current address: Department of Pathology, Virginia Commonwealth University, Richmond, VA, USA.

A preliminary analysis of this work was presented at the 2013 Meeting of the United States and Canadian Academy of Pathology Meeting in Baltimore, MD.

Received 11 March 2014; revised 11 April 2014; accepted 16 April 2014; published online 20 June 2014 sarcomas, originally characterized in the pediatric population, ${ }^{2-5}$ have been found to occur over a wide age range, though they arise predominantly in young adults. ${ }^{6-10}$

We recently reported four undifferentiated round cell sarcomas harboring CIC-DUX4 fusions, ${ }^{11}$ which, together with reported CIC-DUX4L $L^{6}$ cases, we term 'CIC-DUX sarcomas'. These tumors demonstrated clinical behavior at least as aggressive as Ewing sarcomas, with all four patients expiring from disease within 18 months. The tumors had reproducible histomorphology including high-grade nuclear features (vesicular chromatin, moderate nuclear pleomorphism, and prominent nucleoli), lobular growth pattern, geographic necrosis, round cell cytomorphology, patchy clear cell areas, and distinctive foci of myxoid change.

Given the limited experience with these tumors, we sought to characterize an expanded cohort to study CIC-DUX sarcoma histomorphology. As in vitro data suggest that the fusion oncoproteins of these sarcomas may induce expression of 
ETS-family proto-oncogenes, ${ }^{8}$ and as we and others ${ }^{12}$ have noted ERG or FLI1 expression in individual cases, we studied expression of these markers in light of the differential with Ewing sarcoma. Finally, proceeding from our observation of polysomy for chromosome 8 in CIC-DUX cases, ${ }^{11}$ we tested for expression and amplification of the frequently amplified chromosome 8 proto-oncogene, MYC (c-Myc), as well as downstream transcriptional targets.

\section{Materials and methods}

\section{Cohort}

Under IRB-approved protocols, retrospective searches were performed using institutional pathology databases for small round cell sarcomas, predominantly arising in the soft tissue, which had been previously unclassifiable. Four of the cases identified were previously reported. ${ }^{11}$ Six additional cases were identified at the University of Michigan, Cleveland Clinic, and Cedars-Sinai Medical Center. Demographic, pathologic, and clinical follow-up data were tabulated for each case. A previously constructed $^{13}$ tissue microarray of 70 primary and metastatic lesions of 45 cases of Ewing sarcoma (24 classic skeletal, 19 extraskeletal, 2 metastases only) was analyzed for comparison purposes.

\section{Molecular Testing}

We have previously detailed our molecular assays used to establish diagnosis in CIC-DUX sarcomas. Briefly, to assay for rearrangement at the CIC locus, two dual color interphase fluorescence in situ hybridization (FISH) strategies were used. The first used rhodamine labeled BAC clone RP11-569M1, spanning the CIC gene at 19q13, and fluoresceinlabeled RP11-46I12, a centromeric control marker for chromosome 19. The second used conventional 'break apart' probes made from BAC clones RP11317E13 (flanking, centromeric, Cy5 labeled) and RP11-778C1 (flanking, telomeric, fluorescein labeled) to CIC. For the first probe set, tumors showing $>10 \%$ nuclei with three rhodamine signals (CICspanning target split) and two fluorescein signals (centromeric control) were considered positive for rearrangement. For the latter strategy, tumors with $>10 \%$ of nuclei with split green/red signals were considered positive. A final three color dual fusion strategy was used to assay for fusion of either DUX4 or DUX4L and CIC, using probes from RP11-778C1 telomeric to CIC (fluorescein labeled), RP11-521G19, centromeric to DUX4 (rhodamine labeled), and RP11-108K14, centromeric to DUX4L (AQUA labeled). For $M Y C$ amplification and chromosome 8 polysomy testing, commercially available two color probes for the MYC locus at 8q24 and CEN-8 were purchased and used per manufacturer instructions (Poseidon Probes, Veridex, Raritan, NY, USA). Our nested RT-PCR assay for the CIC-DUX4 fusion transcript was used as previously reported,${ }^{11}$ using a primer design and control plasmid developed by Kawamura-Saito et al. ${ }^{8}$ Two cases had also been tested by FISH at Memorial Sloan Kettering Cancer Center, providing additional confirmation of the diagnosis.

\section{Immunohistochemical Analysis}

Immunostain for ERG was performed as described previously using a ready-to-use, prediluted monoclonal antibody against ERG, clone EPR3864 (Ventana Medical Systems, Tucson, AZ) using a Ventana XT autostainer as detailed previously. ${ }^{13-15}$ Immunohistochemical staining for FLI1 (Neomarkers, Fremont, CA, USA), p21/WAF1 (DAKO, Carpinteria, CA, USA) MTDH, (Millipore, Billerica, MA, USA), and CD99 (DAKO) was performed on a DAKO Autostainer (DAKO) using DAKO LSAB + (FLI1 and $\mathrm{MTDH}$ ) or Envision + (p21) and diaminobenzadine as chromogen. Microwave citric acid epitope retrieval was used for FLI1, MTDH, and CD99 prior to staining. Microwave epitope retrieval in $10 \mathrm{mMTris} / 1 \mathrm{mM}$ EDTA pH9 was used for p21. MYC rabbit monoclonal (Y69, Abcam) was used at 1/50 dilution, in buffer CC1 for $36 \mathrm{~min}$ ( $\mathrm{pH} 8.5$ HIER buffer at $95{ }^{\circ} \mathrm{C}$ ), with $32 \mathrm{~min}$ primary incubation at $37^{\circ} \mathrm{C}$. Appropriate negative (no primary antibody) and positive controls were stained in parallel with each set of antibodies studied.

Immunohistochemical scoring was performed (SCS, DGT, RMP) using two scoring systems. A conventional $0-3+$ by proportion ( 0 , negative; $1+$, focal; $2+$ multifocal; $3+$ diffuse) was used for scoring whole-tissue sections stained utilizing antibodies used in our routine clinical practice (ERG, FLI1, MYC, CD99). For scoring the TMA format used for testing the MYC targets p21/WAF1 and MTDH, we used an Allred score $(0-8,0-5$ proportion score summed with a $0-3$ intensity score ${ }^{16}$ for comparison between expression of these targets in CIC-DUX sarcomas and Ewing sarcomas. Specifically, for the Allred score intensity and proportion, both contribute to an overall score (0, none; $1,<1 \% ; 2$, $1-10 \%$; $3,10-33 \%$; $4,33-66 \%$; and $5,>66 \%$ plus an intensity score of 0 , none; 1 , weak; 2 , intermediate; and 3, strong). Distributions of ordinal Allred scores for p21 and MTDH were compared between CIC-DUX sarcomas and Ewing sarcomas by the Mann-Whitney U-test, with significance assumed at an alpha of 0.05 .

\section{Results}

\section{Cohort}

The final cohort included three males and seven females, with age range of 20-43 years, median 35 years. The tumors ranged in size from 3 to $14 \mathrm{~cm}$ 
Table 1 Clinicopathologic features and molecular validation

\begin{tabular}{|c|c|c|c|c|c|c|c|c|c|c|c|}
\hline Case & Reference & Sex & $\begin{array}{l}\text { Age } \\
\text { (years) }\end{array}$ & $\begin{array}{l}\text { Size } \\
(\mathrm{cm})\end{array}$ & Site & $\begin{array}{l}\text { Trans- } \\
\text { location }\end{array}$ & $\begin{array}{l}\text { Positive } \\
\text { assays }\end{array}$ & Negative assays & Metastasis & $\begin{array}{l}\text { Treatment, } \\
\text { in sequence }\end{array}$ & $\begin{array}{l}\text { Outcome } \\
\text { (Mo) }\end{array}$ \\
\hline 1 & Choi et al & $\mathrm{F}$ & 25 & 11 & Right calf & $\mathrm{t}(4 ; 19)$ & $\begin{array}{l}\text { Karyotype, } \\
\text { RT-PCR, } \\
\text { FISH }\end{array}$ & $\begin{array}{l}\text { EWSR1 and SYT } \\
\text { FISH, EWSR1-FLI1/ } \\
\text { ERG and SYT-SSX1/ } \\
\text { 2RT-PCRs }\end{array}$ & $\begin{array}{l}\text { Lung, } \\
\text { brain }\end{array}$ & $\begin{array}{l}\text { AI; IE; resection of primary, } \\
\text { resection of lung and } \\
\text { brain metastases }\end{array}$ & DOD 10 \\
\hline 2 & Choi et al & $\mathrm{F}$ & 32 & 14 & $\begin{array}{l}\text { Right } \\
\text { gluteus/ } \\
\text { pelvis }\end{array}$ & $\mathrm{t}(4 ; 19)$ & $\begin{array}{l}\text { Karyotype, } \\
\text { RT-PCR, } \\
\text { FISH }\end{array}$ & $\begin{array}{l}\text { EWSR1 and SYT } \\
\text { FISH, EWSR1-FLI1/ } \\
\text { ERG and SYT-SSX1/ } \\
\text { 2RT-PCRs }\end{array}$ & Lung & $\begin{array}{l}\text { CVAD; I; E; resection of } \\
\text { primary tumor, high } \\
\text { dose I for recurrent disease, } \\
\text { local radiotherapy for } \\
\text { persistent disease }\end{array}$ & DOD 14 \\
\hline 3 & Choi et al & $\mathrm{F}$ & 20 & 6 & $\begin{array}{l}\text { Left } \\
\text { shoulder }\end{array}$ & $\mathrm{t}(4 ; 19)$ & $\begin{array}{l}\text { RT-PCR, } \\
\text { FISH }\end{array}$ & $\begin{array}{l}\text { EWSR1 and SYT } \\
\text { FISH, EWSR1-FLI1/ } \\
\text { ERG and SYT-SSX1/ } \\
\text { 2RT-PCRs }\end{array}$ & Lung & $\begin{array}{l}\text { AI; high-dose I; surgical } \\
\text { resection of lung } \\
\text { metastases; surgical } \\
\text { resection of primary; } \\
\text { local radiotherapy }\end{array}$ & DOD 17 \\
\hline 4 & Choi et al & M & 43 & 9.8 & Left knee & $\mathrm{t}(4 ; 19)$ & $\begin{array}{l}\text { RT-PCR, } \\
\text { FISH }\end{array}$ & $\begin{array}{l}\text { EWSR1 and SYT } \\
\text { FISH, EWSR1-FLI1/ } \\
\text { ERG and SYT-SSX1/ } \\
\text { 2RT-PCRs }\end{array}$ & Pelvis & $\begin{array}{l}\text { Resection of the primary } \\
\text { Tumor; local radiotherapy }\end{array}$ & DOD 14 \\
\hline 5 & This study & $\mathrm{F}$ & 33 & 6.4 & Right knee & $\mathrm{t}(4 ; 19)$ & FISH & EWSR1 FISH & $\sim$ & $\begin{array}{l}\text { Resection of the primary } \\
\text { tumor; local radiotherapy }\end{array}$ & NED 18 \\
\hline 6 & This study & $\mathrm{F}$ & 36 & 3 & Trapezius & $\mathrm{t}(10 ; 19)$ & FISH & EWSR1 FISH & Lung & $\begin{array}{l}\text { Local radiotherapy, } \\
\text { combination VAC-IE, } \\
\text { en bloc re-resection }\end{array}$ & DOD 11 \\
\hline 7 & This study & M & 38 & 5.2 & Lower arm & $\mathrm{t}(4 ; 19)$ & $\begin{array}{l}\text { RT-PCR, } \\
\text { FISH }\end{array}$ & EWSR1 FISH & $\begin{array}{l}\text { Lung, cubital } \\
\text { fossa } \\
\text { lymph } \\
\text { node }\end{array}$ & $\begin{array}{l}\text { Resection of lung } \\
\text { metastases, local } \\
\text { paliative radiotherapy, } \\
\text { palliative A }\end{array}$ & AWD 17 \\
\hline 8 & This study & $\mathrm{F}$ & 23 & 5.8 & $\begin{array}{l}\text { Left upper } \\
\text { back }\end{array}$ & $\mathrm{t}(4 ; 19)$ & $\begin{array}{l}\text { RT-PCR, } \\
\text { FISH }\end{array}$ & EWSR1 FISH & Lung & $\begin{array}{l}\text { Lung metastectomy, } \\
\text { VAC-IE, stereotactic } \\
\text { radiosurgery to primary and } \\
\text { lung metastases }\end{array}$ & NED 48 \\
\hline 9 & This study & M & 37 & 4.1 & $\begin{array}{l}\text { Right lower } \\
\text { leg }\end{array}$ & $\mathrm{t}(10 ; 19)$ & $\begin{array}{l}\text { Karyotype, } \\
\text { FISH }\end{array}$ & $\begin{array}{l}\text { EWSR1, NR4A3, } \\
\text { FUS FISH, EWSR1- } \\
\text { FLI 1/ERGRTPCR }\end{array}$ & $\begin{array}{l}\text { Groin } \\
\text { lymph } \\
\text { node }\end{array}$ & $\begin{array}{l}\text { Resection of primary, } \\
\text { VAC-IE at } 10 \text { months- } \\
1 \text { year, resection of groin } \\
\text { lymph node metastasis }\end{array}$ & NED 22 \\
\hline 10 & This study & $\mathrm{F}$ & 36 & 6.5 & Right thigh & $\mathrm{t}(4 ; 19)$ & $\begin{array}{l}\text { RT-PCR, } \\
\text { FISH }\end{array}$ & $\begin{array}{l}\text { EWSR1, SYT } \\
\text { FISH }\end{array}$ & New case & New case & New case \\
\hline
\end{tabular}

Abbreviations: A, doxorubicin; AWD, alive with disease; C, cyclophosphamide; D, dactinomycin; DOD, dead of disease; E, etoposide; F, female; FISH, fluorescence in situ hybridization; I, ifosfamide; M, male; NED, no evidence of disease; RT-PCR, reverse transcriptase-polymerase chain reaction; V, vincristine.

(median $6 \mathrm{~cm}$ ) and arose predominantly in soft tissues of the extremities, with half arising in the soft tissues of the lower extremities. The gene fusions identified were $\mathrm{t}(4 ; 19) / C I C-D U X 4$ in $8 / 10$ cases, and $\mathrm{t}(10 ; 19) / C I C-D U X 4 L$ in $2 / 10$ cases, the latter both among the new cases. Of six new cases, follow-up was available for five, where metastasis was noted in $4 / 5$, one demise at 11 months, one case alive with disease progressing on palliative chemotherapy, and three cases showing no evidence of disease at up to 48 months after diagnosis, two of which show no evidence of disease after metastectomy. Table 1 summarizes the clinicopathologic, molecular, and treatment/outcome parameters of these cases.

\section{Morphology}

We prospectively evaluated morphological features described previously as characteristic of CIC-DUX sarcomas, ${ }^{11,12}$ particularly the distinctive myxoid change and patchy clear cell areas, but also including the lobular growth pattern, necrosis, high-grade nuclear features, and presence and extent of spindled cytomorphology. Compared with Cases 1-4 reported previously, ${ }^{11}$ Cases 5-10 showed relatively more extensive myxoid stromal change in 3/6. In Case 9, this morphology resulted in resemblance to extraskeletal myxoid chondrosarcoma or myoepithelioma. Clear cell change was variable, present in 5/6 primary lesions, whereas the one case that lacked clear cell change showed this feature in its metastasis. Foci of spindled cellular morphology were identified in 5/6 cases. Metastatic deposits were available for review for Cases 7 and 9; both showed a degree of dense, sheetlike growth exceeding that of the primary tumor. Figures 1 and 2 illustrate the morphological features seen, whereas Table 2 summarizes the morphological observations by case.

\section{Immunophenotype and Genotype}

Both the cases previously reported ${ }^{11}$ and those newly identified were studied by immunohistochemistry (IHC) for expression of Ewing sarcoma-associated 
markers CD99 and ETS transcription factor family members ERG and FLI1. CD99 was expressed in $7 / 7$ cases, focal in $5 / 7$, multifocal and diffuse in the two remaining cases, though the pattern of staining was cytoplasmic without the classic membranous enhancement seen in Ewing sarcoma
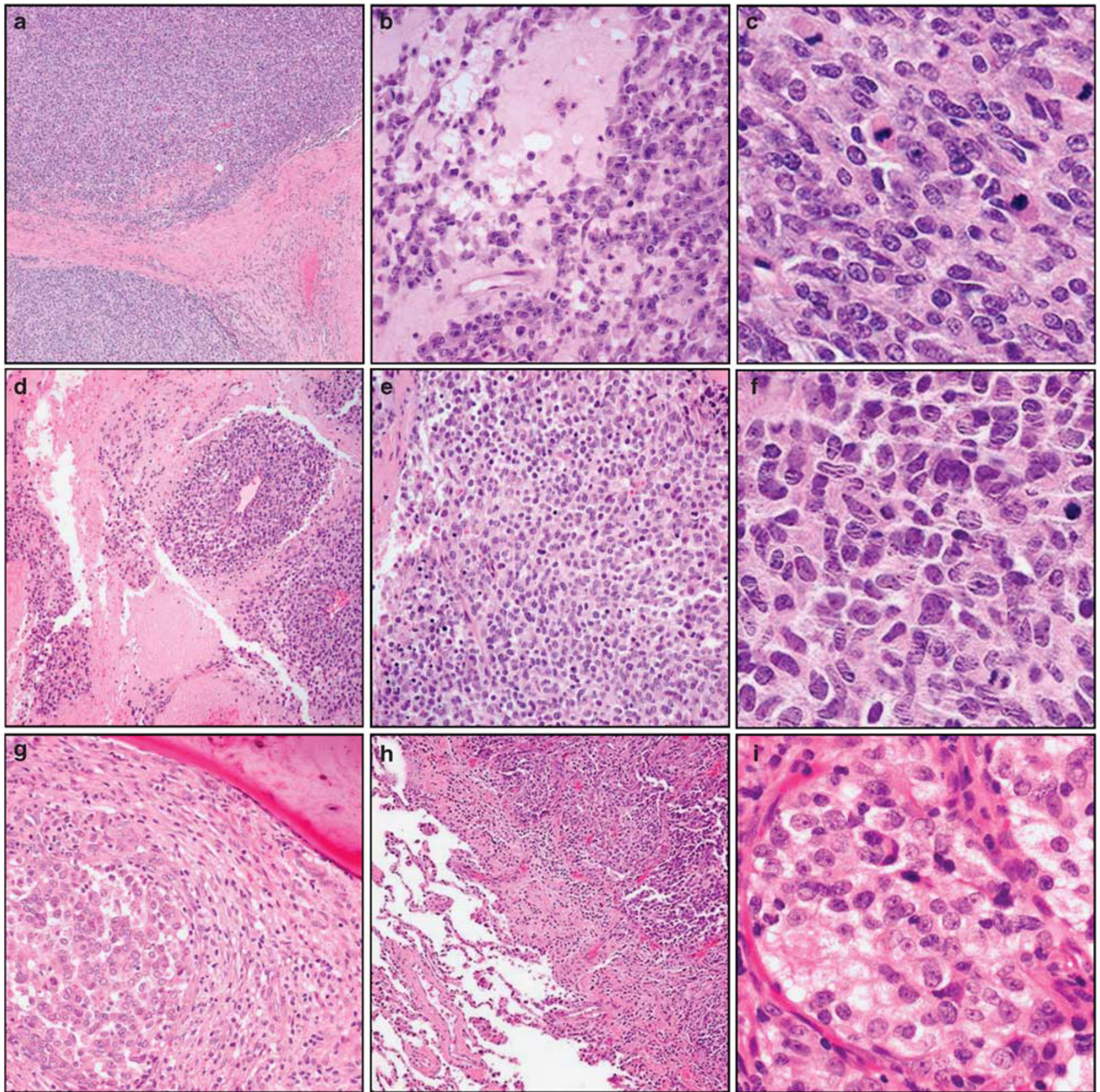

Figure 1 Morphological features of CIC-DUX Sarcomas, cases 5-7. Case 5 demonstrates prominent lobular growth (a, $\times 10)$ with focal stromal myxoid change $(\mathbf{b}, \times 40)$. High-grade cytology was apparent with brisk mitosis, with mild to moderate nuclear variation beyond that seen in a Ewing sarcoma $(\mathbf{c}, \times 40$, zoom). Case 6 , a t(10;19) case, showed predominant, geographic necrosis $>50 \%$ of the untreated primary, with sparing of perivascular tumor $(\mathbf{d}, \times 20)$. Areas of pale to clear cytoplasm were focal $(\mathbf{e}, \times 40)$, whereas the cytology showed moderate nuclear pleomorphism and a syncytial appearance $(\mathbf{f}, \times 40$, zoom). Case 7 showed metaplastic ossification of the peritumoral fibrous septae (g, $\times 40)$; the case progressed to lung metastasis $(\mathbf{h}, \times 20)$, where focal areas of pale to clear cytoplasm were apparent $(\mathbf{i}, \times \mathbf{4 0}$, zoom).

Figure 2 Morphological features of CIC-DUX Sarcomas, Cases 8-10. Case 8 demonstrates cytomorphology ranging from round to more spindled $(\mathbf{a}, \times 20)$ with myxoid areas associated with spindled growth $(\mathbf{b}, \times 20)$. High-grade cytology with nucleoli was apparent $(\mathbf{c}, \times 40$, zoom). Case 9, a t(10;19) case, showed superficial extension nearing the skin surface (d, $\times 10)$ and striking morphology evocative of a myoepithelial neoplasm $(\mathbf{e}, \times 20)$. The subsequent lymph node metastasis showed dense, cellular growth more similar to other cases $(\mathbf{f}, \times 10)$. Case 10 showed a necrotic lesional core $(\mathbf{g}, \times 10)$. Several foci at the periphery showed stromal myxoid change $(\mathbf{h}, \times 40$, zoom), whereas spindled cellular areas were notable $(\mathbf{i}, \times 40)$. In Case 9, CD99 positivity was diffuse $(\mathbf{j}, \times 20)$ albeit without a membranous pattern $(\mathbf{k}, \times 40)$. No more than focal staining was seen in most cases $(\mathbf{l}, \times 40)$. 

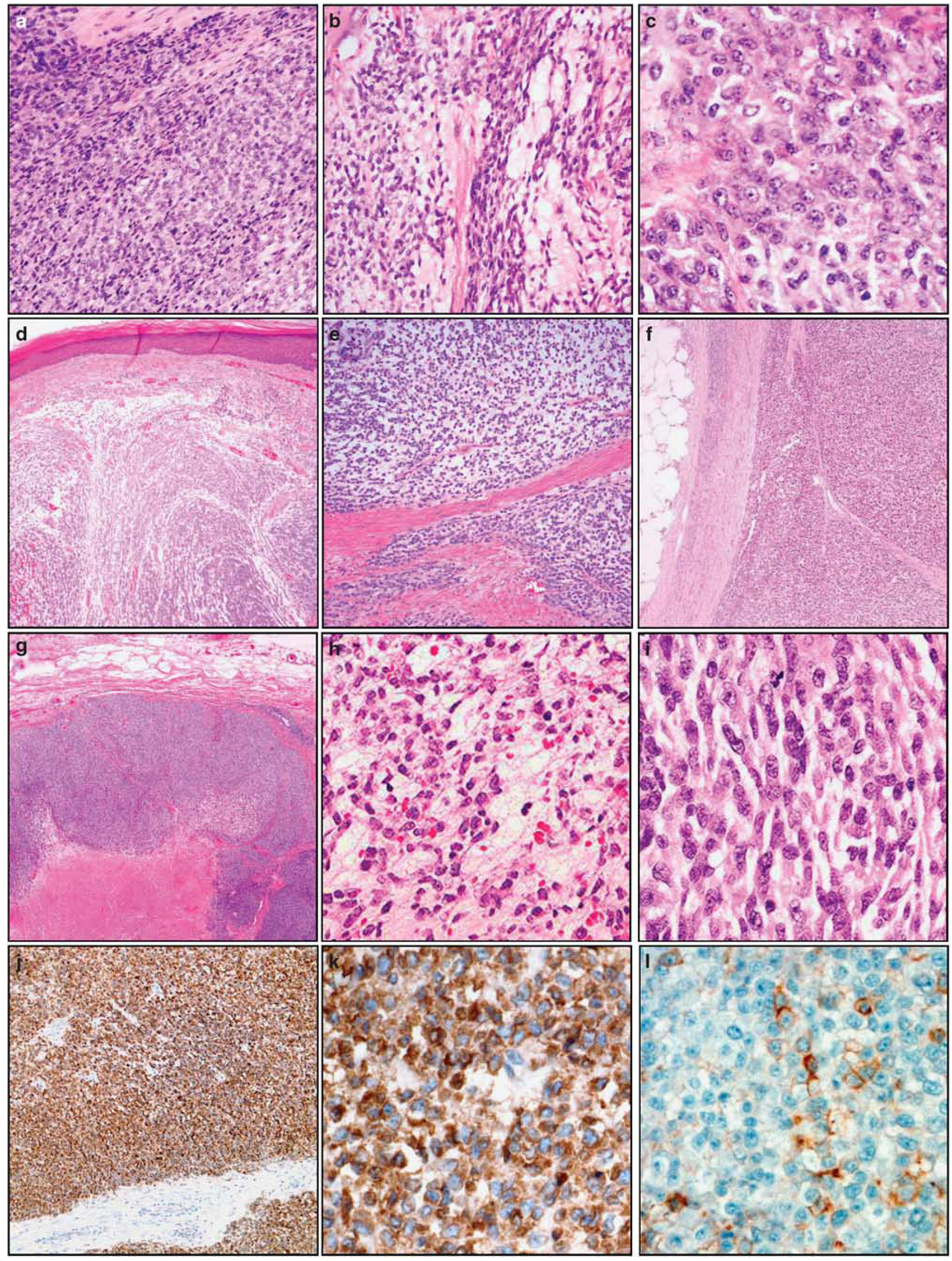
Table 2 Morphological features of new cases and metastases

\begin{tabular}{|c|c|c|c|c|c|c|c|c|c|}
\hline Case & $\begin{array}{l}\text { Lesion } \\
\text { studied }\end{array}$ & Site & $\begin{array}{l}\text { Septate } \\
\text { growth }\end{array}$ & Necrosis & Nuclear features & $\begin{array}{l}\text { Clear } \\
\text { cell areas }\end{array}$ & Myxoid & $\begin{array}{l}\text { Spindled } \\
\text { cytology }\end{array}$ & Other notes \\
\hline 5 & Primary & Right knee & Present & $\begin{array}{l}\text { Single cell and } \\
\text { focus of tumor } \\
\text { cell necrosis }\end{array}$ & $\begin{array}{l}\text { Vesicular chromatin, } \\
\text { less prominent } \\
\text { nucleoli, moderate } \\
\text { pleomorphism }\end{array}$ & Multifocal & Focal & Focal & $\sim$ \\
\hline 6 & Primary & $\begin{array}{l}\text { Right } \\
\text { trapezius }\end{array}$ & Present & $\begin{array}{l}\sim 50 \% \text {, Geographic } \\
\text { with perivascular } \\
\text { sparing }\end{array}$ & $\begin{array}{l}\text { Vesicular chromatin, } \\
\text { less prominent } \\
\text { nucleoli, moderate } \\
\text { pleomorphism }\end{array}$ & Focal & Multifocal & Focal & $\sim$ \\
\hline 7 & $\begin{array}{l}\text { Primary } \\
\text { and } \\
\text { metastasis }\end{array}$ & $\begin{array}{l}\text { Lower arm, } \\
\text { lung }\end{array}$ & Present & $\begin{array}{l}\sim 5 \%, \text { Focal tumor } \\
\text { cell necrosis in } \\
\text { primary and } \\
\text { metastasis }\end{array}$ & $\begin{array}{l}\text { Vesicular chromatin, } \\
\text { prominent nuclei, } \\
\text { moderate } \\
\text { pleomorphismin } \\
\text { primary and metastasis }\end{array}$ & $\begin{array}{l}\text { Absent in } \\
\text { primary, } \\
\text { present in } \\
\text { metastasis }\end{array}$ & Focal, primary & Absent & $\begin{array}{l}\text { Metaplastic bone } \\
\text { in peritumoral } \\
\text { septae, prominent } \\
\text { lymphohistiocytic } \\
\text { infiltrate only } \\
\text { in primary }\end{array}$ \\
\hline 8 & Primary & $\begin{array}{l}\text { Left upper } \\
\text { back }\end{array}$ & Present & $\begin{array}{l}\sim 5 \%, \text { Multifocal } \\
\text { tumor cell necrosis }\end{array}$ & $\begin{array}{l}\text { Vesicular chromatin, } \\
\text { prominent nuclei, } \\
\text { moderate } \\
\text { pleomorphism }\end{array}$ & Multifocal & Multifocal & $\begin{array}{l}\sim 10 \%, \\
\text { Multifocal }\end{array}$ & $\sim$ \\
\hline 9 & $\begin{array}{l}\text { Primary } \\
\text { and } \\
\text { Metastasis }\end{array}$ & $\begin{array}{l}\text { Right lower } \\
\text { leg, groin } \\
\text { lymph node }\end{array}$ & Present & $\begin{array}{l}\text { Focal in primary, } \\
\sim 30 \% \text {, geographic } \\
\text { with perivascular } \\
\text { sparing in lymph } \\
\text { node metastasis }\end{array}$ & $\begin{array}{l}\text { Vesicular chromatin, } \\
\text { less prominent } \\
\text { nucleoli, moderate } \\
\text { pleomorphism mostly } \\
\text { in metastasis }\end{array}$ & $\begin{array}{l}\text { Prominent } \\
\text { in metastasis }\end{array}$ & $\begin{array}{l}\text { Predominant in } \\
\text { primary, focal } \\
\text { in metastasis }\end{array}$ & $\begin{array}{l}\text { Prominent in } \\
\text { primary, } \\
\text { patchy in } \\
\text { metastasis }\end{array}$ & $\begin{array}{l}\text { Marked increased } \\
\text { cellularity in } \\
\text { groin node } \\
\text { metastasis }\end{array}$ \\
\hline 10 & Primary & Right thigh & Present & $\begin{array}{l}\sim 50 \% \text {, Geographic } \\
\text { with perivascular } \\
\text { sparing }\end{array}$ & $\begin{array}{l}\text { Vesicular chromatin, } \\
\text { prominent nuclei, } \\
\text { mild pleomorphism }\end{array}$ & Focal & Prominent & $\begin{array}{l}\sim 30 \%, \\
\text { Multfocal }\end{array}$ & $\begin{array}{l}\text { Myxoid } \\
\text { periphery, } \\
\text { cellular core } \\
\text { of lesion }\end{array}$ \\
\hline
\end{tabular}

(Figure 2j-l). ERG was positive in 9/10 cases; FLI1 was positive in $8 / 8$ cases. Overall, FLI1 positivity was more extensive and intense than that of ERG. The patterns of FLI1 and ERG are demonstrated in Figure 3; Table 3 details the immunophenotype by case.

We previously observed trisomy 8 in two CIC-DUX cases where karyotyping was performed in routine clinical workup. ${ }^{11}$ Among the six newly identified cases, cytogenetic data were only available for one additional case, a t(10;19) CIC-DUX4L case, which also showed trisomy 8. Given the known locus of MYC (c-Myc) on chromosome 8, we hypothesized that this oncogene might be of significance in CICDUX sarcomas. Immunohistochemical MYC expression was positive, mostly diffuse, in 10/10 cases. On the basis of this observation, we tested for amplification of the MYC locus by FISH, using probes spanning the $M Y C$ locus to evaluate copy number, and centromeric controls for chromosome 8 as a surrogate for ploidy. Trisomy for chromosome 8 was seen in 5/7 cases successfully tested, confirming the cytogenetic observation of trisomy 8 in one of the two previous cases (the hybridization was unsuccessful in the other). Amplification of the $M Y C$ locus, present as multiple additional copies, was identified in six of seven cases; two cases harbored amplification without chromosome 8 polysomy. Figure 4 shows representative MYC FISH and IHC findings; Table 3 summarizes immunophenotypic and FISH results by case.

Two established transcriptional targets of MYC signaling include Metadherin (AEG-1/Astrocyte Elevated Gene 1/Lyric) encoded at $M T D H^{17}$ and p21 (WAF1/CIP1) encoded at CDKN1A. ${ }^{18}$ To study how the pattern of expression of these transcriptional targets in CIC-DUX sarcomas compares with Ewing sarcoma, we used a tissue microarray, constructed of Ewing sarcoma cases described previously. ${ }^{13}$ Comparing semiquantitative Allred IHC scores ${ }^{16}$ between CIC-DUX and Ewing sarcoma cases, we found that MTDH was expressed similarly $(P=0.20)$, whereas $\mathrm{p} 21$ expression was significantly greater in the CIC-DUX cases $(P<0.001)$ (see Figure 5).

\section{Discussion}

Recent molecular advances, especially next generation sequencing, have allowed identification of a number of subtypes of undifferentiated round cell and spindle cell sarcomas as defined by the 2013 WHO classification, ${ }^{19}$ several of which lack EWSR1 gene rearrangement ${ }^{12}$ and harbor characteristic alternative genomic alterations. Among recently recognized molecular subtypes of these undifferentiated sarcomas are tumors harboring CIC-DUX4 and CIC-DUX4L fusions, ${ }^{6,11}$ which may constitute a substantial subset of such cases. ${ }^{6}$ The distinctive features described by others,,$^{2,3,5-8}$ in our prior cohort, ${ }^{11}$ and replicated herein, lead us to suggest that these tumors be regarded as a distinct entity, defined not only by their distinctive molecular but also by reproducible histopathologic characteristics.

We would argue, as have others, ${ }^{12}$ that diagnostic recognition of this entity as a high-risk malignancy 


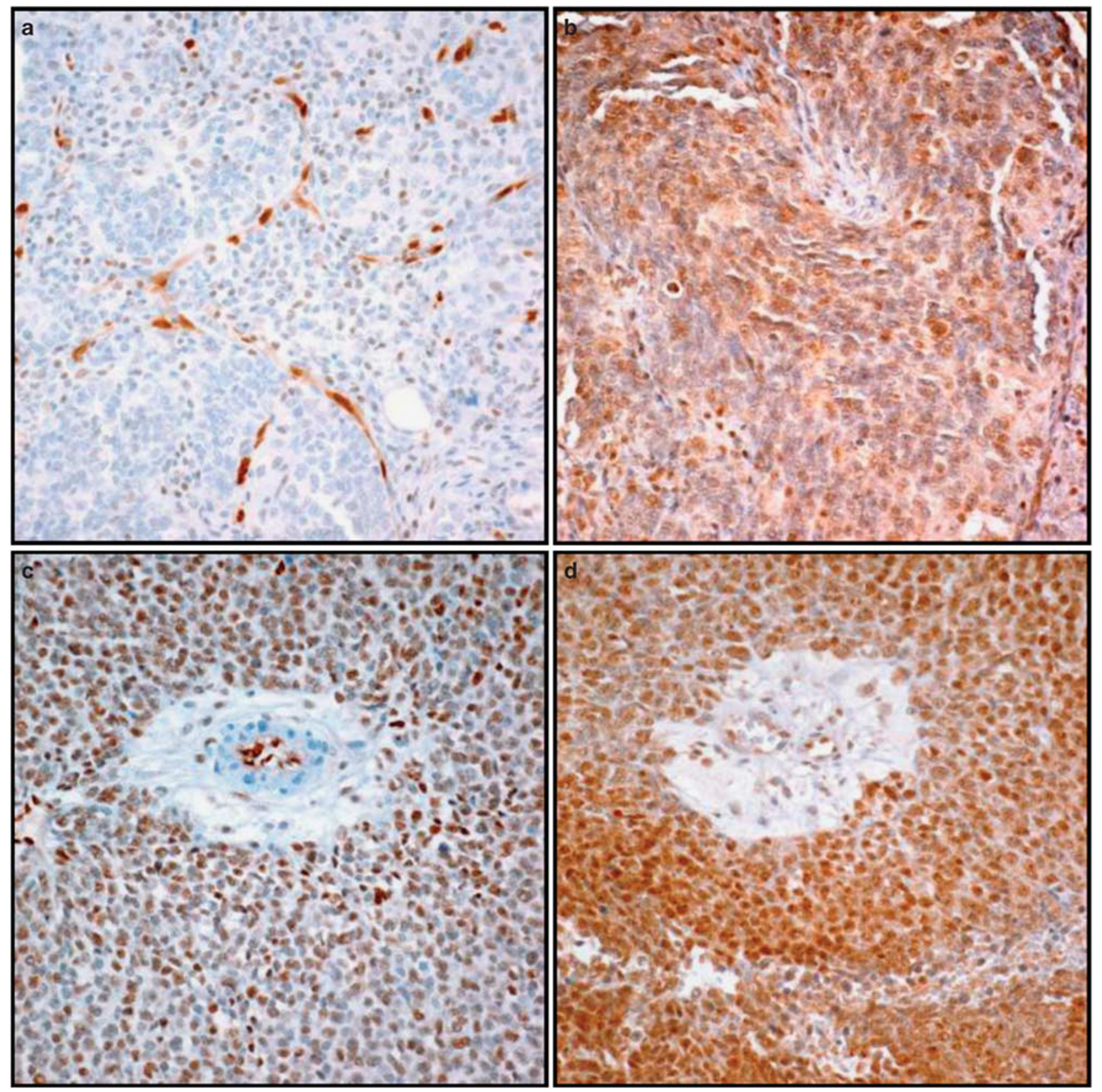

Figure 3 ERG and FLI1 positivity of CIC-DUX Sarcomas. Representative micrographs from Case 7 (a, b), Case 9 (c, d), and Case 10 (e, f), for ERG (a, c, e) and FLI1 (b, d, f) illustrate positivity of these Ewing sarcoma-associated markers. ERG ranged from focal (Case 7, panel a, scored as $1+$ ) to $3+$, diffuse in Cases 9 and 10. FLI1 showed overall greater proportion and intensity; each of these was graded as $3+$ positivity.

(at least analogous to Ewing sarcoma) is important given the different treatment considerations, as compared with conventional adult soft tissue sarcomas. Though interdisciplinary consultation is recommended, national comprehensive cancer network general guidelines for adult soft tissue sarcomas, depending on stage, may recommend surgery with observation, with or without adjuvant or neoadjuvant radiotherapy ${ }^{20}$ rather than a Ewing sarcomatype multidrug chemotherapeutic protocol. Data on treatment and response to therapy in CIC-DUX sarcomas remain limited; recognition of CIC-DUX sarcomas will be requisite to make progress in this regard going forward. We report herein two cases showing metastatic progression with prolonged survival after combination chemotherapy (including the Ewing sarcoma regimen, VAC-IE) and radiotherapy, now without evidence of disease at 22 and 48 months. These outcomes suggest that a multidrug Ewing sarcoma-type regimen may be advantageous in these patients and call for larger studies of treatments and outcomes going forward. 


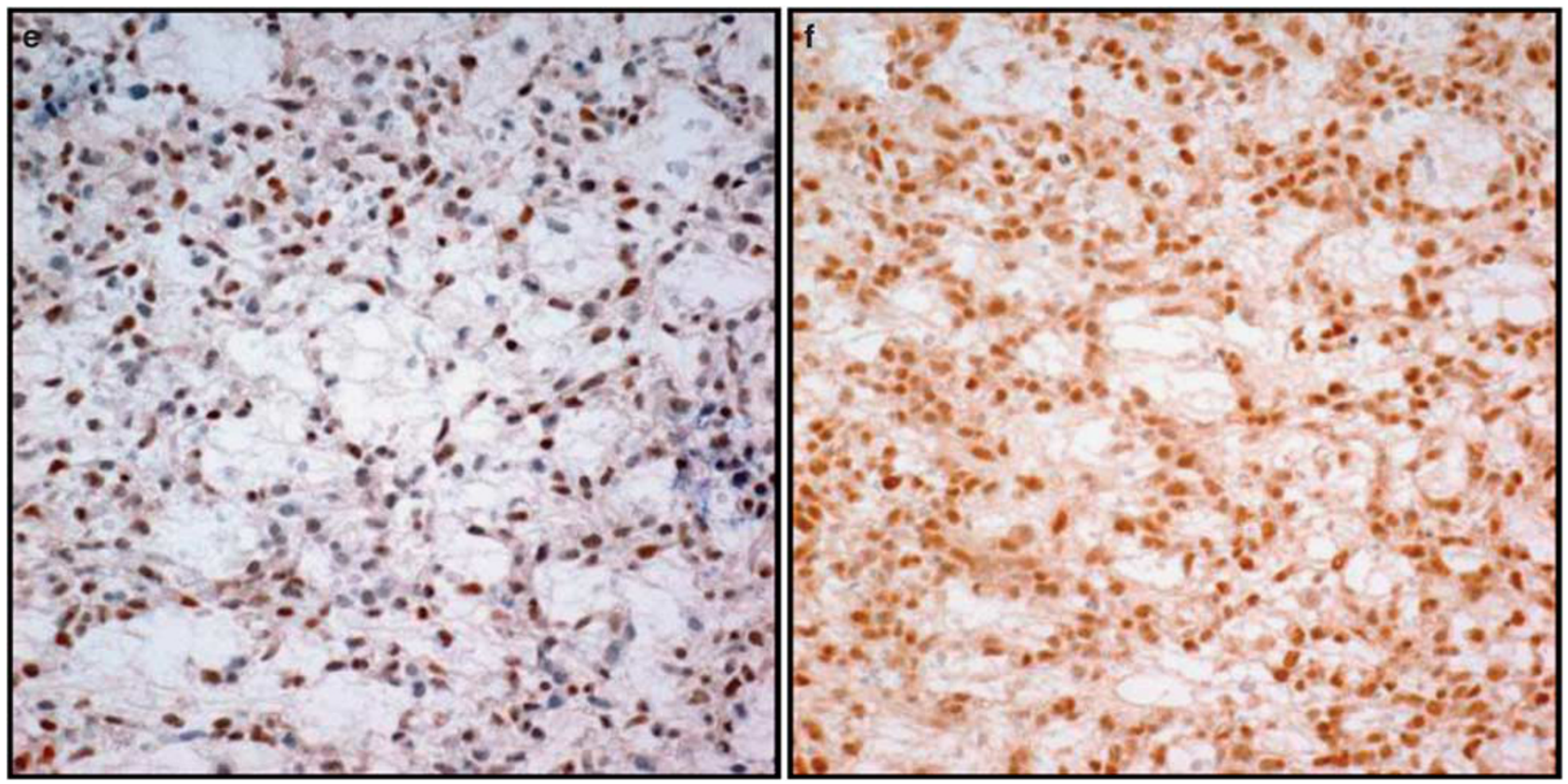

Figure 3 (Continued).

Table 3 Molecular and immunophenotypic features

\begin{tabular}{|c|c|c|c|c|c|c|c|c|c|}
\hline Case & $\begin{array}{l}\text { Lesion } \\
\text { studied }\end{array}$ & Site & $\begin{array}{l}\text { Chr.8, } \\
\text { cytogenetics }\end{array}$ & $\begin{array}{l}\text { Chr.8, } \\
\text { FISH }\end{array}$ & $\begin{array}{l}\text { MYC } \\
\text { ampli- } \\
\text { fication }\end{array}$ & $\begin{array}{l}c-M y c \\
I H C\end{array}$ & $\begin{array}{l}E R G \\
I H C\end{array}$ & $\begin{array}{l}\text { FLI1 } \\
\text { IHC }\end{array}$ & $\begin{array}{l}\text { CD99 } \\
\text { IHC }\end{array}$ \\
\hline 1 & Primary, Choi et al & Right calf & +8 , Trisomy & $\mathrm{NC}$ & $\mathrm{NC}$ & $2+$ & $2+$ & $2+$ & $1+$ \\
\hline 2 & Primary, Choi et al & $\begin{array}{l}\text { Right gluteus/ } \\
\text { pelvis }\end{array}$ & +8 , Trisomy & $\begin{array}{l}+8, \\
\text { Trisomy }\end{array}$ & + & $3+$ & $2+$ & $3+$ & $1+$ \\
\hline 3 & Primary, Choi et al & Left shoulder & ND & - & + & $3+$ & $3+$ & $3+$ & $2+$ \\
\hline 4 & Primary, Choi et al & Left knee & ND & - & + & $3+$ & $3+$ & $3+$ & $1+$ \\
\hline 5 & Primary & Right knee & ND & $\begin{array}{l}+8, \\
\text { Trisomy }\end{array}$ & + & $3+$ & 0 & ND & ND \\
\hline 6 & Primary & Right trapezius & ND & $\begin{array}{l}+8, \\
\text { Trisomy }\end{array}$ & - & $3+$ & $2+$ & ND & ND \\
\hline 7 & Metastasis & Lung & ND & NC & $\mathrm{NC}$ & $1+$ & $1+$ & $3+$ & $2+$ \\
\hline 8 & Primary & Left upper back & ND & $\begin{array}{l}+8, \\
\text { Trisomy }\end{array}$ & + & $3+$ & $2+$ & $2+$ & ND \\
\hline 9 & Metastasis & Groin lymph node & +8 , Trisomy & $\mathrm{NC}$ & NC & $3+$ & $2+$ & $3+$ & $3+$ \\
\hline 10 & Primary & Right thigh & ND & $\begin{array}{l}+8, \\
\text { Trisomy }\end{array}$ & + & $3+$ & $2+$ & $3+$ & $1+$ \\
\hline
\end{tabular}

Abbreviations: Chr., chromosome; FISH, fluorescence in situ hybridization; IHC, immunohistochemistry; NC, non-contributory technical failure; ND, tissue insufficient-not done.

From the standpoint of histomorphology, our observations on newly collected cases confirm observations from our previously reported cohort ${ }^{11}$ and further establish characteristic, if variable, histomorphological features. A distinctive and prevalent feature is the observation of myxoid change, which in some of the newly identified cases was extensive, resulting in some resemblance to soft tissue myoepithelial carcinoma or extraskeletal myxoid chondrosarcoma. Characteristic also is the patchy clear cell change, which ranged from focal to diffuse in the newly identified cases, apparent only in the metastasis of one case. We also observed areas showing spindled to fusiform cytomorphology, often associated with areas of myxoid stromal change, similar to that seen in myxoid synovial sarcoma, ${ }^{21}$ which were not observed in our prior series. The nodular growth of sheets of high-grade cells with attenuated cytoplasm separated by fibrous septae is a consistent architectural feature. Nuclear morphology, including a vesicular nuclear appearance, often with readily identified nucleoli and mild-to-moderate pleomorphism, is distinctive as compared with Ewing sarcoma. For that matter, rosette formation was not identified in any case evaluated. Prominent 

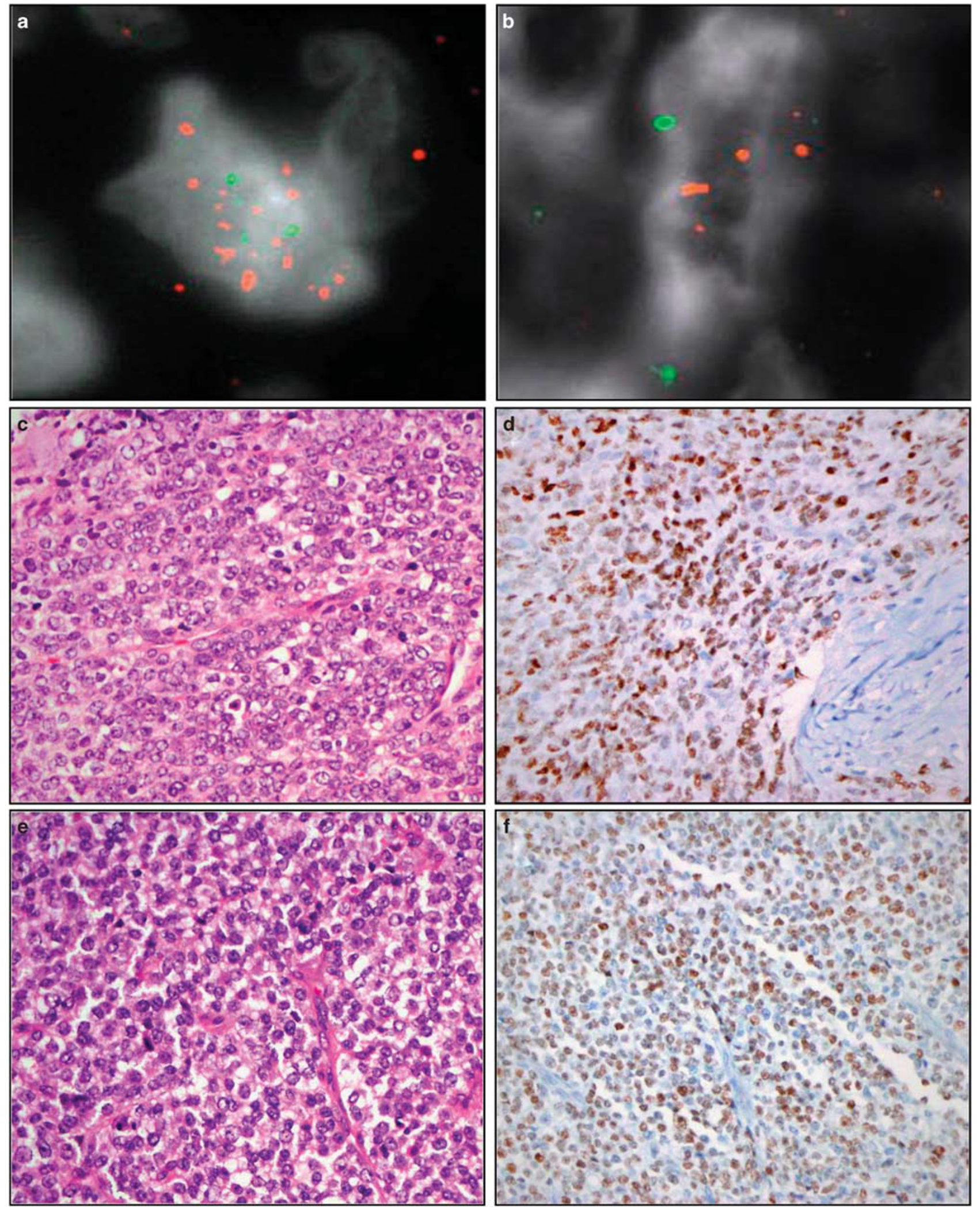

Figure 4 MYC amplification and overexpression. (a) Representative epifluorescence micrograph of Case 2 with chromosome 8 trisomy, indicated by three (green) centromeric probes, confirming the cytogenetic observation. The MYC locus is amplified (red). (b) Similar micrograph for case 8, which demonstrated disomy for chromosome 8 (green), still with MYC locus amplification (red). Both cases 2 (c, d) and $3(\mathbf{e}, \mathbf{f})$, demonstrated high-grade cytology and diffuse expression of MYC protein by IHC in $>50 \%$ of lesional cells. 

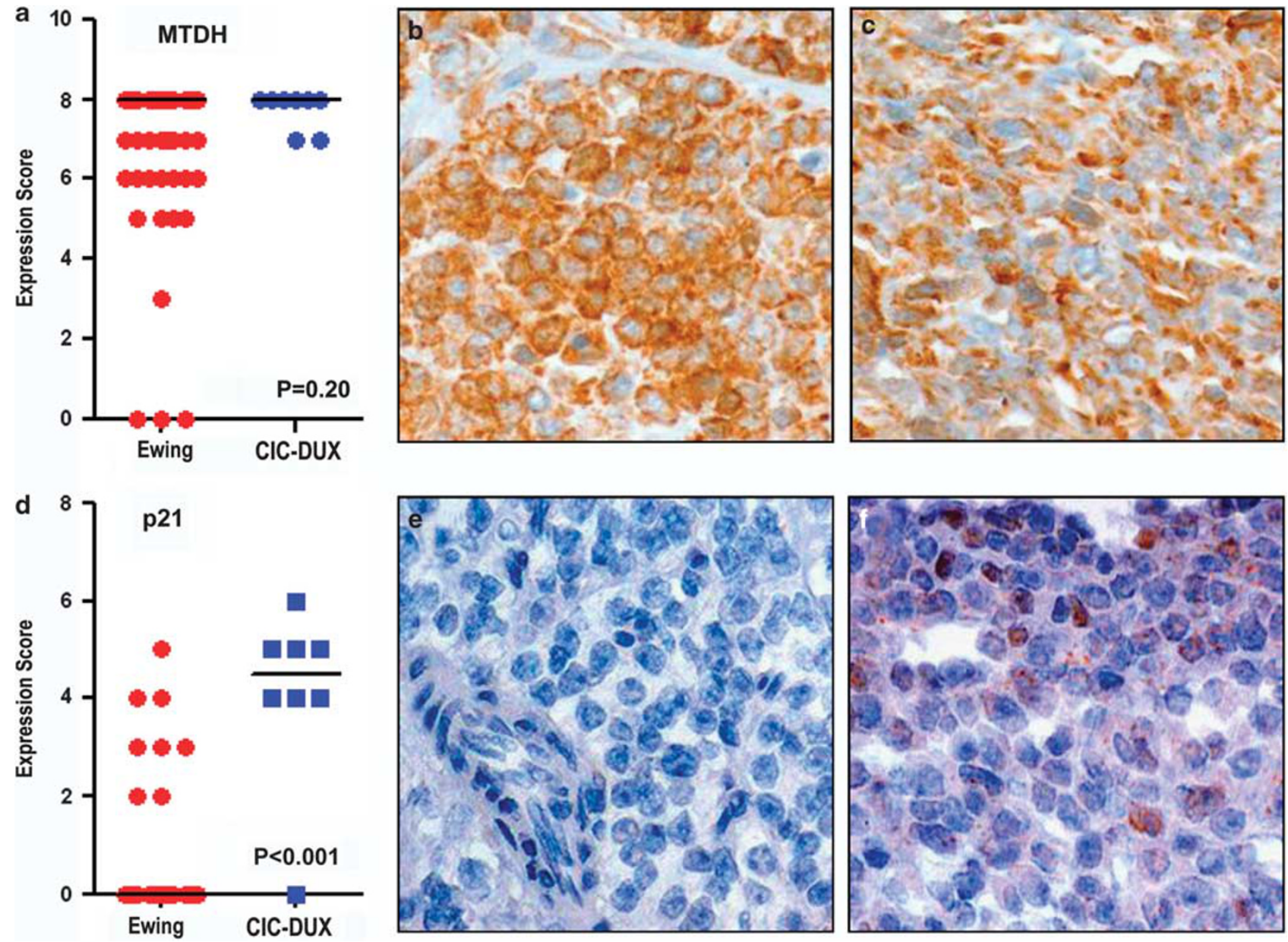

Figure 5 Differential expression of MYC targets MTDH and p21 in CIC-DUX sarcomas and Ewing sarcomas. (a) A dot plot comparing MTDH IHC scores in CIC-DUX sarcomas to Ewing sarcomas (median and Mann-Whitney $P$-value). Both entities show a similar pattern of membranocytoplasmic expression of this marker (b, representative Ewing; c, CIC-DUX). (d) Similar plot for p21, showing differential expression between these tumors, with representative micrographs showing lack of nuclear expression in Ewing (e) and patchy/subset expression in CIC-DUX (f).

geographic necrosis, often striking at low power, is a feature of the majority of cases; a rim of preserved tumor cells is often present around tumoral vasculature. Single-cell necrosis, imparting a 'starry sky' appearance, ${ }^{12}$ was observed in these cases, as well.

The diagnosis of Ewing sarcoma of bone or extraskeletal soft tissues is clinical and morphological, assisted by adjunctive molecular studies. CD99 IHC, when positive with a diffuse membranous pattern, is supportive of a diagnosis of Ewing sarcoma. Although most cases of CIC-DUX sarcoma demonstrated some CD99 immunoreactivity, in our experience, the CD99 pattern in CIC-DUX sarcomas is different from that seen in Ewing sarcoma cases. We, ${ }^{11}$ and others ${ }^{2,5-8}$ have observed mostly focal to patchy staining, though our single CIC-DUX4L case with diffuse CD99 (although not membranous) is cautionary and correlates a with a few other reported CIC-DUX cases that showed diffuse CD99 $2,3,6$ immunoreactivity.

More specific to the molecular abnormalities seen in Ewing sarcomas is IHC for two members of the
ETS family of proto-oncogenic transcription factors, ERG, and FLI1. FLI1 IHC has been used as supportive evidence of Ewing sarcoma. ${ }^{22}$ More recently, a monoclonal antibody against the closely related ETS family member, ERG, in widespread clinical use as a specific marker of prostatic adenocarcinoma ${ }^{23,24}$ and benign and neoplastic endothelium, ${ }^{25}$ has shown cross reactivity with FLI1, and hence promise in diagnosis of Ewing sarcomas harboring FLI1 ${ }^{13}$ or ERG rearrangement, ${ }^{26}$ depending on the dilution used. Although nuclear pleomorphism, nucleoli, geographic necrosis, spindling, clear cell change, and, especially, myxoid change are not typically seen in Ewing sarcoma, the two tumors may be difficult to distinguish in small samples. We observed positivity for FLI1 and/or ERG in essentially all of the CIC-DUX sarcomas studied, a finding similar to that expected in Ewing sarcoma, and therefore, a relevant and significant pitfall in diagnosis.

The observations of FLI1 and ERG immunoreactivity in our CIC-DUX4 sarcomas corroborate those 
noted in previous cases, ${ }^{4,6}$ as well as a very recent report that these sarcomas very frequently coexpress nuclear WT1 and ETS-family factors, ${ }^{27}$ the former overlapping with the immunophenotype of desmoplastic small round cell tumor. Although such immunostains may have a role for triage of limited biopsy samples, we regard confirmation of a morphological diagnosis of Ewing sarcoma of bone or extraskeletal soft tissue (or exclusion of Ewing in a possible CIC-DUX case) to be best accomplished through molecular testing for EWSR1 rearrangement. Also notable are recently reported findings of strong induction of expression of other ETSfamily transcription factors, including ETV1, ETV4 (PEA3), and ETV5, in gene expression profiling studies. $^{8,27}$ This observation implies testable hypotheses regarding the oncogenic mechanism of the CIC-DUX fusion transcripts. We are exploring the potential for use of these additional ETS members as diagnostic adjuncts by RNA in situ hybridization. ${ }^{28}$

On the basis of observation of additional copies of chromosome 8 in the karyotypes in three of our cases, we hypothesized that $M Y C$ amplification might be important in the development of CICDUX sarcomas. We observed polysomy for chromosome 8 in the majority of our cases, with amplification of the $M Y C$ locus in 6/7 and MYC protein overexpression in all cases tested. Although this is not entirely surprising given the high prevalence of MYC amplification or overexpression in high-grade carcinomas, lymphomas, and sarcomas, ${ }^{29-33}$ this observation may have potential therapeutic implications, in light of a number of emerging strategies to target this pathway. ${ }^{29}$

The differential expression of two well-studied MYC targets, p21 $1^{18}$ and MTDH $^{17}$ in CIC-DUX sarcomas as compared with Ewing sarcomas is also worth noting. Expression of MTDH (Metadherin/ AEG-1/Astrocyte Elevated Gene 1/Lyric), which we found to be a shared and prevalent feature of both CIC-DUX sarcomas and Ewing sarcoma, may be important mechanistically and as a therapeutic target. A growing body of literature implicates MTDH as a specific mediator of lung metastasis in breast adenocarcinoma, ${ }^{34}$ a provocative finding in light of the frequent lung metastasis among the CICDUX sarcomas (and, for that matter, among Ewing sarcomas). Expression of MTDH has been recently noted as a poor prognostic factor in Ewing sarcoma and other sarcomas, ${ }^{35,36}$ and proposed as a targetable cell surface marker. ${ }^{37}$ In contrast, we found that expression of p21 was significantly greater in CIC-DUX sarcomas. Though only a subset of nuclei in these tumors was positive for p21, this observation identifies another difference in cell signaling between CIC-DUX and Ewing sarcomas despite their shared expression of, and implicitly, shared dependency on, oncogenic ETS transcription factor signaling.

In summary, based on the findings of an expanded set of CIC-DUX sarcoma cases, we have validated prior observations of characteristic demographic features, aggressive clinical behavior, and histomorphology. Recognition of this entity is clinically relevant, and we highlight prevalent ERG and FLI1 positivity as an important consideration during diagnostic workup. Finally, prevalent $M Y C$ amplification with differential expression of downstream targets may represent a therapeutically targetable oncogenic pathway in CIC-DUX sarcomas, but additional studies are needed.

\section{Acknowledgments}

We acknowledge the University of Michigan Molecular Pathology Research Laboratory (UM-MPRL) for core facility usage for this project, as well as the University of Michigan Anatomic Pathology Research Projects Funding. We thank Dr David Shimizu of Honolulu, HI, for patient follow-up data. We thank Dr Cristina Antonescu of Memorial Sloan Kettering Cancer Center for performing diagnostic testing for CIC gene rearrangement in two cases before they were retested at UM-MPRL and included in this study.

\section{Disclosure/conflict of interest}

The authors declare no conflict of interest.

\section{Note added to the proof}

Following acceptance of this manuscript, Specht et al. reported similar findings regarding FLI1, ERG, and CD99 expression in their cohort of 21 CIC-DUX sarcomas (Specht K, Sung YS, Zhang L, et al. Distinct transcriptional signature and immunoprofile of CICDUX4 fusion-positive round cell tumors compared to EWSR1-rearranged Ewing sarcomas: further evidence toward distinct pathologic entities. Genes Chromosomes Cancer 2014;53:622-633). Though ERG expression (assayed with more dilute antibody) was less prevalent than we observed, they also further report prevalent expression of WT1. Together, these reports amplify the distinctive features of CIC-DUX sarcomas and argue for their prospective recognition as a new class of undifferentiated small round-cell sarcomas.

\section{References}

1 Pawel BR, Hamoudi AB, Asmar L, et al. Undifferentiated sarcomas of children: pathology and clinical behavior-an Intergroup Rhabdomyosarcoma study. Med Pediatr Oncol 1997;29:170-180.

2 Graham C, Chilton-MacNeill S, Zielenska M, et al. The CIC-DUX4 fusion transcript is present in a subgroup of pediatric primitive round cell sarcomas. Hum Pathol 2012;43:180-189.

3 Machado I, Cruz J, Lavernia J, et al. Superficial EWSR1-negative undifferentiated small round cell 
sarcoma with CIC/DUX4 gene fusion: a new variant of Ewing-like tumors with locoregional lymph node metastasis. Virchows Arch 2013;463:837-842.

4 Rakheja D, Goldman S, Wilson KS, et al. Translocation (4;19)(q35;q13.1)-associated primitive round cell sarcoma: report of a case and review of the literature. Pediatr Dev Pathol 2008;11:239-244.

5 Yoshimoto M, Graham C, Chilton-MacNeill S, et al. Detailed cytogenetic and array analysis of pediatric primitive sarcomas reveals a recurrent CIC-DUX4 fusion gene event. Cancer Genet Cytogenet 2009;195:1-11.

6 Italiano A, Sung YS, Zhang L, et al. High prevalence of CIC fusion with double-homeobox (DUX4) transcription factors in EWSR1-negative undifferentiated small blue round cell sarcomas. Genes Chromosomes Cancer 2012;51:207-218.

7 Kajtar B, Tornoczky T, Kalman E, et al. CD99-positive undifferentiated round cell sarcoma diagnosed on fine needle aspiration cytology, later found to harbour a CIC-DUX4 translocation: a recently described entity. Cytopathology 2013;25:129-132.

8 Kawamura-Saito M, Yamazaki Y, Kaneko K, et al. Fusion between CIC and DUX4 up-regulates PEA3 family genes in Ewing-like sarcomas with t(4;19)(q35;q13) translocation. Hum Mol Genet 2006;15:2125-2137.

9 Richkind KE, Romansky SG, Finklestein JZ. $\mathrm{t}(4 ; 19)(\mathrm{q} 35 ; \mathrm{q} 13.1)$ : a recurrent change in primitive mesenchymal tumors? Cancer Genet Cytogenet 1996; 87:71-74

10 Somers GR, Shago M, Zielenska M, et al. Primary subcutaneous primitive neuroectodermal tumor with aggressive behavior and an unusual karyotype: case report. Pediatr Dev Pathol 2004;7:538-545.

11 Choi EY, Thomas DG, McHugh JB, et al. Undifferentiated small round cell sarcoma with $\mathrm{t}(4 ; 19)(\mathrm{q} 35 ; \mathrm{q} 13.1)$ CIC-DUX4 fusion: a novel highly aggressive soft tissue tumor with distinctive histopathology. Am J Surg Pathol 2013;37:1379-1386.

12 Antonescu C. Round cell sarcomas beyond Ewing: emerging entities. Histopathology 2014;64:26-37.

13 Tomlins SA, Palanisamy N, Brenner JC, et al. Usefulness of a monoclonal ERG/FLI1 antibody for immunohistochemical discrimination of Ewing family tumors. Am J Clin Pathol 2013;139:771-779.

14 Bhalla R, Kunju LP, Tomlins SA, et al. Novel dualcolor immunohistochemical methods for detecting ERG-PTEN and ERG-SPINK1 status in prostate carcinoma. Mod Pathol 2013;26:835-848.

15 Young A, Palanisamy N, Siddiqui J, et al. Correlation of urine TMPRSS2:ERG and PCA3 to ERG + and total prostate cancer burden. Am J Clin Pathol 2012;138:685-696.

16 Collins LC, Botero ML, Schnitt SJ. Bimodal frequency distribution of estrogen receptor immunohistochemical staining results in breast cancer: an analysis of 825 cases. Am J Clin Pathol 2005;123:16-20.

$17 \mathrm{Hu} \mathrm{G}$, Wei Y, Kang Y. The multifaceted role of MTDH/ AEG-1 in cancer progression. Clin Cancer Res 2009;15: 5615-5620.

18 Coller HA, Grandori C, Tamayo P, et al. Expression analysis with oligonucleotide microarrays reveals that MYC regulates genes involved in growth, cell cycle, signaling, and adhesion. Proc Natl Acad Sci U S A 2000;97:3260-3265.

19 Fletcher CDM. World Health Organization, International Agency for Research on Cancer. WHO classification of tumours of soft tissue and bone, 4th edn. IARC Press: Lyon, 2013.
20 von Mehren M, Benjamin RS, Bui MM, et al. Soft tissue sarcoma, version 2.2012: featured updates to the NCCN guidelines. J Natl Compr Canc Netw 2012;10: 951-960.

21 Krane JF, Bertoni F, Fletcher CD. Myxoid synovial sarcoma: an underappreciated morphologic subset. Mod Pathol 1999;12:456-462.

22 Folpe AL, Hill CE, Parham DM, et al. Immunohistochemical detection of FLI-1 protein expression: a study of 132 round cell tumors with emphasis on CD99positive mimics of Ewing's sarcoma/primitive neuroectodermal tumor. Am J Surg Pathol 2000;24:1657-1662.

23 Brenner JC, Feng FY, Han S, et al. PARP-1 inhibition as a targeted strategy to treat Ewing's sarcoma. Cancer Res 2012;72:1608-1613.

24 Tomlins SA, Rhodes DR, Perner S, et al. Recurrent fusion of TMPRSS2 and ETS transcription factor genes in prostate cancer. Science 2005;310:644-648.

25 Miettinen M, Wang ZF, Paetau A, et al. ERG transcription factor as an immunohistochemical marker for vascular endothelial tumors and prostatic carcinoma. Am J Surg Pathol 2011;35:432-441.

26 Wang WL, Patel NR, Caragea M, et al. Expression of ERG, an Ets family transcription factor, identifies ERG-rearranged Ewing sarcoma. Mod Pathol 2012;25: 1378-1383.

27 Specht K, Sung YS, Richter G, et al. A Comparative Immunohistochemical and Molecular Study of CIC-DUX4-Fusion Positive Round Cell Sarcomas Versus EWSR1-Rearranged Ewing Sarcomas - Further Evidence toward Distinct Pathologic Entities. Mod Pathol 2014;27:11-33; A105.

28 Smith SC, Palanisamy N, Choi EK, et al. Overexpression of ETS-Family Transcription Factors in CIC-DUX4 Sarcomas: A Useful Diagnostic Adjunct? Mod Pathol 2014;27:11-33; A103.

29 Dang CV. MYC on the path to cancer. Cell 2012;149: 22-35.

30 Dauphinot L, De Oliveira C, Melot T, et al. Analysis of the expression of cell cycle regulators in Ewing cell lines: EWS-FLI-1 modulates p57KIP2and c-Myc expression. Oncogene 2001;20:3258-3265.

31 Deming SL, Nass SJ, Dickson RB, et al. C-myc amplification in breast cancer: a meta-analysis of its occurrence and prognostic relevance. Br J Cancer 2000;83:1688-1695.

32 Hoffman B, Amanullah A, Shafarenko M, et al. The proto-oncogene c-myc in hematopoietic development and leukemogenesis. Oncogene 2002;21:3414-3421.

33 Sollazzo MR, Benassi MS, Magagnoli G, et al. Increased c-myc oncogene expression in Ewing's sarcoma: correlation with Ki67 proliferation index. Tumori 1999;85:167-173.

34 Brown DM, Ruoslahti E. Metadherin, a cell surface protein in breast tumors that mediates lung metastasis. Cancer Cell 2004;5:365-374.

35 Milhem MM, Knutson T, Yang S, et al. Correlation of MTDH/AEG-1 and HOTAIR Expression with Metastasis and Response to Treatment in Sarcoma Patients. J Cancer Sci Ther 2011;Suppl 5:004.

36 Wang F, Ke ZF, Sun SJ, et al. Oncogenic roles of astrocyte elevated gene-1 (AEG-1) in osteosarcoma progression and prognosis. Cancer Biol Ther 2011;12:539-548.

37 Orentas RJ, Yang JJ, Wen X, et al. Identification of cell surface proteins as potential immunotherapy targets in 12 pediatric cancers. Front Oncol 2012;2:194. 